\title{
Riparian vegetation restoration: Does social perception reflect ecological value?
}

\author{
Pedro Arsénio ${ }^{1}$ (D) | Patricia María Rodríguez-González ${ }^{2}$ (D) | Ivan Bernez ${ }^{3}$ | \\ Filipe S. Dias, 5,6 | Miguel Nunes Bugalho ${ }^{4}$ | Simon Dufour ${ }^{7}$
}

\author{
${ }^{1}$ LEAF - Linking Landscape, Environment, \\ Agriculture and Food, School of Agriculture, \\ University of Lisbon, Lisbon, Portugal \\ ${ }^{2}$ Forest Research Centre, School of \\ Agriculture, University of Lisbon, Lisbon, \\ Portugal \\ ${ }^{3}$ INRA, Agrocampus Ouest, UMR 985 ESE, \\ Ecology and Ecosystem Health, Rennes Cedex, \\ France \\ ${ }^{4}$ Centre for Applied Ecology "Prof. Baeta \\ Neves" (CEABN - InBIO), School of \\ Agriculture, University of Lisbon, Lisbon, \\ Portugal \\ ${ }^{5} \mathrm{CIBIO}-$ InBIO, Research Centre in \\ Biodiversity and Genetic Resources, Associate \\ Laboratory, University of Porto, Vairão, \\ Portugal \\ ${ }^{6} \mathrm{CIBIO}-\mathrm{InBIO}$, Research Centre in Biodiversity \\ and Genetic Resources, Associate Laboratory, \\ School of Agriculture, University of Lisbon, \\ Lisbon, Portugal \\ ${ }^{7}$ Université Rennes 2, CNRS UMR LETG, \\ Rennes Cedex, France
}

\section{Correspondence}

Patricia María Rodríguez González, Azevedo Gomes Building, Forest Research Centre, School of Agriculture, University of Lisbon, Tapada da Ajuda, Lisbon 1349-017, Portugal. Email: patri@isa.ulisboa.pt

\section{Funding information}

AESN, AFB / SNB (Ministère de l'écologie) ORE dia-PFC; Campus France, Grant/Award Number: FCT \& Campus France through Bilateral Agreements PESSOA programme / Hubert Curien; European Cooperation in Science and Technology, Grant/Award Number: CA16208 - CONVERGES: Knowledge Conversion for Enhancing Management of European Riparian Ecosystems and Services; Fundação para a Ciência e a Tecnologia, Grant/ Award Numbers: IF/00059/2015, IF/01171/ 2014, PTDC/ASP-SIL/28593/2017, UID/ AGR/00239/2013 and UID/AGR/04129/ 2019

\begin{abstract}
Social-ecological contexts are key to the success of ecological restoration projects. The ecological quality of restoration efforts, however, may not be fully evident to stakeholders, particularly if the desired aesthetic experience is not delivered. Aesthetically pleasing landscapes are more highly appreciated and tend to be better protected than less appealing landscapes, regardless of their ecological value. Positive public perception of restoration actions may therefore facilitate stakeholder involvement and catalyse recognition of ecological improvement. Here we aim to contrast aesthetical perception and ecological condition in headwater river reaches restored through passive ecological restoration in study areas in Portugal (Alentejo) and France (Normandy). We recorded structural and functional indicators of riparian vegetation to monitor the ecological condition of study sites along a passive restoration trajectory. Aesthetical perception indicators were assessed through stakeholder inquiries developed under a semantic differential approach. We analysed perception responses to changes in the riparian ecosystems resulting from passive ecological restoration across different geographical contexts and social groups. The analysed social groups comprised stakeholders (environmental managers and landowners) and university students (landscape architecture and geography students). Results indicate that (a) visual preferences often do not reflect changes in ecological condition, (b) perception of the restoration process is strongly context dependent, and (c) experience and cultural background affect perception of ecological condition across the different social groups analysed. Clear identification of relevant stakeholder groups (those interested in or directly affected by restoration), effective communication, and stakeholder engagement are therefore essential for assuring the success of river restoration projects.
\end{abstract}

\section{KEYWORDS}

aesthetical perception, functional diversity, headwater streams, passive ecological restoration, riparian forest, river restoration, semantic differential approach, stakeholder engagement 


\section{1 | INTRODUCTION}

The social dimension of riparian ecosystem restoration has gained increasing recognition, as ecological restoration cannot be properly undertaken without considering the socio-economic context of the ecosystem to be restored (Dufour, Rodríguez-González, \& Laslier, 2019; Swart et al., 2018). Ecosystem recovery resulting from restoration efforts may not be properly perceived by the public and by stakeholders (those interested in or directly affected by restoration), as perception is frequently driven by aesthetical experience, rather than by the recognition of ecological quality (e.g., Hands \& Brown, 2002; Purcell, Friedrich, \& Resh, 2002). Aesthetically pleasing landscapes are more likely to be appreciated and protected than less appealing landscapes, regardless of their ecological value (Gobster, Nassauer, Daniel, \& Fry, 2007). Conflicting aesthetic preferences and ecological objectives have been increasingly addressed within the socialecological dimensions of ecological restoration (Cottet, Piégay, \& Bornette, 2013; Junker \& Buchecker, 2008).

Research interest in social perceptions of the ecological condition of riparian systems has grown, particularly regarding aspects such as the perception of wood (i.e., woody debris) in rivers (Chin et al. 2014; Le Lay et al., 2008; Piégay et al., 2005), wetlands (Cottet et al., 2013), and invasive species (Cottet, Piola, Le Lay, Rouifed, \& Rivière-Honegger, 2015). Research concerning social dimensions of restoration has addressed the effects of stream restoration on the perception of riverine ecological condition. The analysis of data from 26 river restoration measures undertaken in Germany highlights the important role of social perception in defining the success or failure of river restoration measures (Jähnig et al., 2011). In New Zealand, McCormick, Fisher, and Brierley (2015) discussed the extent of explicit management "cues" in the perception of the degree of achievement of restoration goals (i.e., how evaluations of naturalness are a function of the degree to which people perceive the landscape to be "cared for"). In an urban context, aquatic condition indicators were used to analyse social perception of water quality and pollution (Hong, Chang, \& Chung, 2018). Other components of the river system, such as riparian vegetation, are particularly conflictive in terms of social perception due to potentially opposite understandings of functions and (dis)services (Dufour et al., 2019; Kondolf \& Yang, 2008). Riparian vegetation can be valued for human well-being in terms of its contribution to biodiversity conservation and flood and pollution control (Naiman, Décamps, \& McClain, 2005). However, it may also be negatively perceived, as the development of woody vegetation is frequently associated with land abandonment and neglected or unsafe terrain (Purcell et al., 2002). In addition to contrasting stakeholder interests, riparian vegetation processes are not equally valued everywhere, and regional complexity must be better understood in order to appropriately adjust restoration actions (for European examples, see Dufour \& Piégay, 2009, and Hughes, Colston, \& Mountford, 2005; for an example from New Zealand, see McCormick et al., 2015). Thus, although restoration actions concern both ecological and social dimensions, these dimensions are rarely studied together (for wetland examples, see Zhao, Wang, Luo, Xing, \& Sun, 2017, and Cottet et al., 2013).
Moreover, research on the social perception of restoration efforts across social groups has gained increasing legitimacy because, as Gobster and Hull (2000) and Kondolf and Yang (2008) stated, restoration projects are fundamentally a social phenomenon. Public acceptance and support may ultimately determine the success and sustainability of a project, and the restoration process can also be dedicated to the satisfaction of social needs. Various authors have conducted research on the relation between visual preferences and ecological quality in riverine environments. Preferences for "wild" versus "managed" riverine landscapes were investigated by Van den Berg and Koole (2006), and the authors concluded that open, managed river margins were aesthetically preferred over forested, nonmanaged, "wild" ones. Junker and Buchecker (2008) used photographic simulations to test aesthetic responses to river corridors under different postrestoration levels of naturalness and concluded that aesthetic preferences were positively related to ecomorphological indicators of high ecological quality and high naturalness. However, results from other studies indicate otherwise. For example, Zhao et al. (2017) suggested that the relationship between ecological quality and visual aesthetic preference is not linear due to intermediate stages in ecological quality evaluation. For example, dense vegetation cover can be perceived by the general public as "unsafe," thus lowering people's aesthetic appreciation of these sites.

There is ongoing debate about how different social groups perceive changes in riparian vegetation, particularly concerning changes resulting from passive restoration (PR). PR consists of removing human disturbances (e.g., fire, grazing, and abstraction of river water) in order to allow for natural or unassisted recovery (Holl \& Aide, 2011). As PR involves minimal management intervention in an ecosystem, thereby allowing the conditions for natural succession to proceed, it may have ecological and economic advantages. PR has been applied to the removal of persistent disturbances such as grazing. Browsing of seedlings by herbivores prevents riparian recruitment (Painter, Beschta, Larsen, \& Ripple, 2018), whereas trampling provokes disturbance and erosion of soil and habitat degradation (Nomiya et al., 2003). In riparian ecosystems, herbivore exclusion may sometimes be all that is necessary to achieve restoration success, thus requiring a relatively small budget (Forget, Carreau, Coeur, \& Bernez, 2013). However, PR approaches involve potential drawbacks in terms of perception. The longer recovery time typically required in PR can be perceived as project failure and, in the worst of cases, may lead to the premature termination of a project by a landowner who would like to see more rapid or visible results, because areas subject to PR are often perceived as unused land (Zahawi, Reid, \& Holl, 2014). This is particularly relevant in headwaters, which represent $60-80 \%$ of the cumulative length of river networks across landscapes (Benda, Hassan, Church, \& May, 2005; Brooks \& Colburn, 2011), but which have received relatively little attention compared to larger rivers (but see Mallik, Newaz, Mackereth, \& Shahi, 2011).

In this study, we aim to further investigate how people perceive scenic quality in headwater streams, to explore the relationships between such perceptions and ecological condition, and to examine how these perceptions change along a PR trajectory. Specifically, we 
(a) assessed the visual perceptions of different social groups across PR trajectories; (b) analysed two different geographical contexts (Portugal and France) and the respective survey-participant nationalities to assess if these perceptions are context dependent, in terms of both the geographical location where the restoration is implemented and the cultural background of the survey participants; and (c) investigated the relation between visual perception and observed changes in ecological and functional indicators of sites at various stages along a restoration trajectory.

\section{2 | METHODS}

\section{1 | Ecological condition}

The two study areas are in the Alentejo region of Portugal and in Normandy, France. They are similar enough (see full descriptions below) to enable comparability, in that they are both headwaters and are both subject to similar environmental pressures and restoration approaches, but they have the differences required for the purposes of the study (i.e., they are located in different biogeographic regions).

The Portuguese study area is located in the Tagus river basin (Figure 1). The climate is subhumid Mediterranean, with a mean annual temperature of $16^{\circ} \mathrm{C}$ and an average rainfall of $730 \mathrm{~mm} /$ year (Agencia Estatal de Meteorologia \& Instituto de Meteorologia, 2011). The study area's streams and rivers (see Table 1) are classified as "rivers of the sedimentary deposits of Tagus and Sado - type S3" according to the Portuguese national river typology (Instituto Nacional da Água, 2008) developed under the Water Framework Directive (WFD) criteria. Sampling was conducted in two headwater streams with a mean drainage area of $21.0 \mathrm{~km}^{2}$, where high floods are common during autumn and winter, but where flow decreases and streams dry out during late spring and summer. The dominant land uses in the study area are cork oak (Quercus suber) woodlands (42\%), agricultural crops (27\%), and plantations of blue gum Eucalyptus globulus Labill. (9\%). Grazing by cattle and sheep is common throughout the study area as part of the traditional silvo-pastoral management of cork-oak woodland (montado), and over the last decade, there has been increasing implementation of Forest Stewardship Council certification (Dias, Bugalho, Rodríguez-González, Albuquerque, \& Cerdeira, 2015). Riparian vegetation consists mainly of a dense shrub and tree layer dominated by willows such as Salix salviifolia Brot. and Salix atrocinerea Brot. and with lower strata composed of several different shrubs, ferns, forbs, and graminoid species such as Rubus ulmifolius Schott, Osmunda regalis L., Lythrum salicaria L., Juncus effusus L., and Holcus lanatus L. The study area comprises three sites in two headwater streams that are subject to a PR scheme based on cattle exclusion by means of fence installation. The scheme was implemented as part of the Forest Stewardship Council certification process (see Dias et al., 2015 for details) for the cork-oak woodlands. Fieldwork was done in 2016 at one site before certification (i.e., subject to grazing pressure), at one site after 1 year of certification, and at one site after 8 years of certification; the three sites were identified as nonrestored (NR), short-term restored (ST), and long-term restored $(\mathrm{LT})$, respectively.

The French study area is located in the Sélune river basin, Normandy, France (Figure 1). The climate is oceanic, with a mean annual temperature of $11.6^{\circ} \mathrm{C}$ and an average rainfall of $760 \mathrm{~mm} /$ year (www.meteofrance.com). The study area's streams and rivers (see Table 1 ) are classified as very small streams of the Armorican Massif river typology developed according to the WFD criteria (Chandesris, Wasson, Pella, Sauquet, \& Mengin, 2006). Sampling was conducted in the Oir River, a headwater stream with permanent flow and a drainage area of $84 \mathrm{~km}^{2}$. Its landscape has long been shaped by agricultural activities (which represent $94 \%$ of the landcover at watershed scale), leading to a heterogeneous landscape including crops and pastures surrounded by hedgerows and streams. Riparian vegetation along the streams comprises a mosaic of open grazed meadows and woody corridors (dominated by Alnus glutinosa [L.] Gaertn. and Salix atrocinerea Brot.) resulting from diverse management practices including mowing and tree cutting by local farmers and authorities (Sawtschuk, Delisle, Mesmin, \& Bernez, 2014). Over the past decades, intensification of farming practices had strongly impacted the headwater streams and their habitats. Since 2004, local organizations and authorities have been implementing a PR programme at the watershed scale in order to recover a good ecological state of surface water (a WFD requirement) and improve the sustainability of salmonid populations. The restoration technique employed is based on excluding cattle to prevent streambank destruction by trampling and grazing (see Forget et al., 2013, for details). Sampling was conducted at the Oir River study sites just before the installation of cattle fences in 2004 (NR), after 1 year in 2005 (ST), and after 10 years in 2014 (LT).

Field data in the Portuguese and French study areas were collected by means of floristic inventories conducted in $15 \times 1 \mathrm{~m}$ plots set up between the stream and the fence, in which all vascular plant species present were identified to species level (based on Castroviejo et al., 1986-2015, and Stace, 2010). In the French study area, 36 permanent plots equally distributed along four sectors of the stream (four different landowners) were established. These were sampled in 2004 (NR), 2005 (ST), and 2014 (LT). In the Portuguese study area, a space-fortime substitution approach was used (Pickett, 1989) due to the absence of a long-term monitoring scheme. In this case, 13 plots were equally distributed across the three study sites (NR, ST, and LT sites) and were sampled in 2016.

Ecological change and natural succession were assessed based on structural and functional indicators of riparian vegetation derived from the floristic inventories. First, we calculated plant species groups indicating community structural complexity related with successional stages (proportion of trees, shrubs, ferns, and climbers) for all sampled plots. Second, we obtained functional indicators of the riparian community. The functional traits approach has been increasingly used in applied ecology, as traits serve as a common currency when comparing responses across biogeographical regions with different species compositions (McGill, Enquist, Weiher, \& Westoby, 2006), traits enable the linking of community composition with ecosystem 

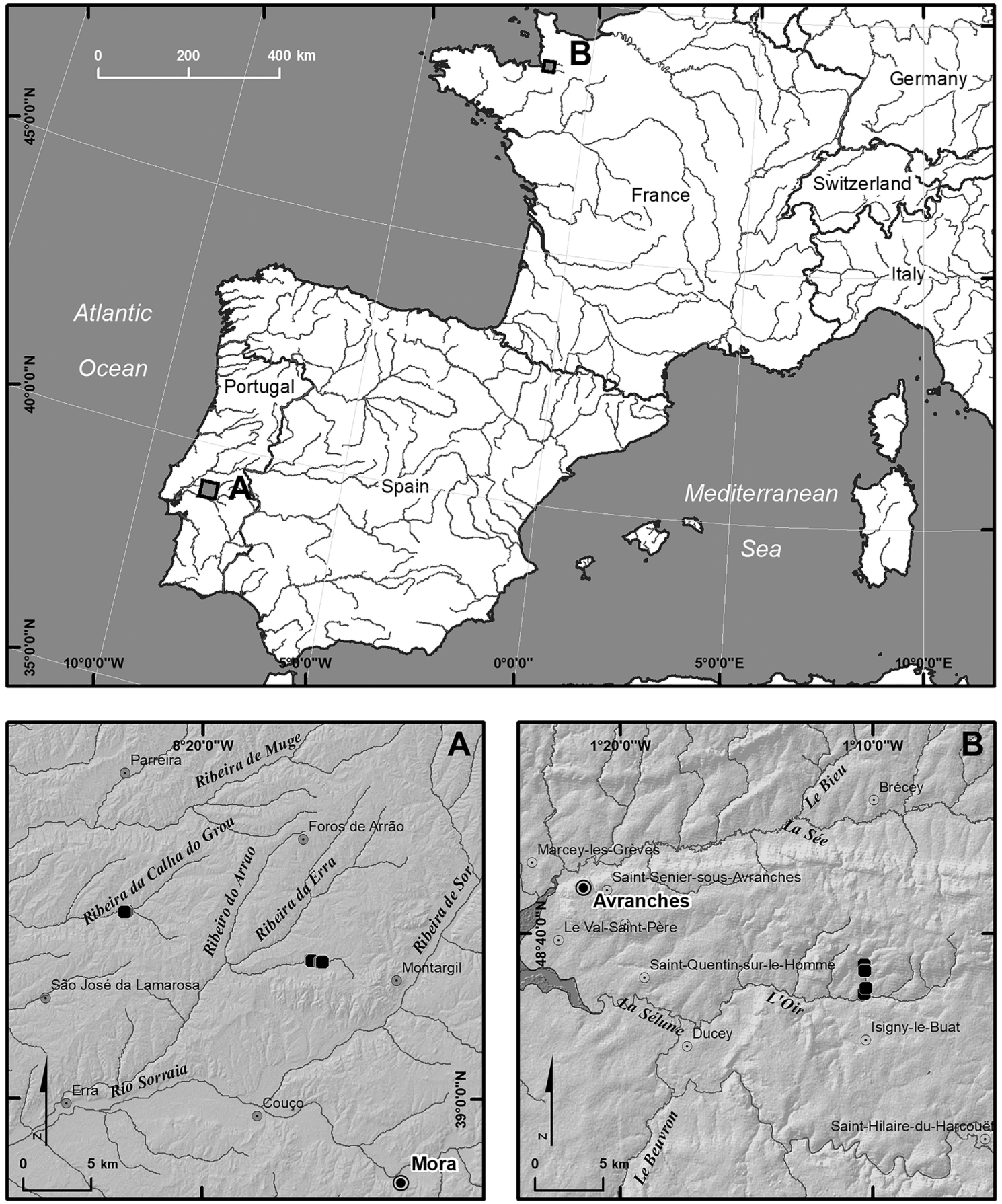

FIGURE 1 Location of the studied headwater streams in Portugal and France. Above, location of study areas in Portugal (A) and France (B) within western Europe (Lambert Azimuthal Equal-Area Projection); below, location of sampled plots in Portugal (A) and France (B; WGS84,

Web Mercator [Auxiliary Sphere] Projection)

functioning (Dufour et al., 2019; Van Looy et al., 2019), and previous research has revealed clear evidence for a loss of functional diversity in degraded systems (Laliberté et al., 2010). The plant functional traits and ecological features we used were life form (sensu Raunkiaer, 1934), life span, leaf persistence, dominant reproduction type, and ecological strategy (sensu Grime, 1977). These were retrieved from the BiolFlor Database (Klotz, Kühn, \& Durka, 2002). Life form is a useful way to functionally classify species based on the location of perennating tissues in relation to ground level and is related to their capacity to persist under different environmental conditions and disturbances such as grazing (Whittaker, 1975). Life span is linked with population persistence and is associated with disturbance, whereby annual species characterize pioneer communities (PérezHarguindeguy et al., 2013). Leaf persistence relates to the nutrientuse strategy of a plant, thus providing an indirect index of important plant traits such as potential growth rate, nutrient-use efficiency, 
TABLE 1 Characteristics of the French and Portuguese sampling sites

\begin{tabular}{|c|c|c|}
\hline & Portugal (Alentejo) & France (Normandy) \\
\hline Studied rivers & $\begin{array}{l}\text { Ribeira da Calha do } \\
\text { Grou; Ribeira de } \\
\text { Maltim }\end{array}$ & Oir River \\
\hline \multicolumn{3}{|l|}{ Landscape matrix } \\
\hline Land use & $\begin{array}{l}\text { Cork-oak silvo- } \\
\text { pastoral system } \\
\text { (montado) }\end{array}$ & $\begin{array}{l}\text { Meadows with } \\
\text { grazing }\end{array}$ \\
\hline Type of livestock & Cattle & Cattle \\
\hline \multicolumn{3}{|l|}{ Riparian systems } \\
\hline $\begin{array}{l}\text { Dominant riparian } \\
\text { canopy }\end{array}$ & $\begin{array}{l}\text { Salix atrocinerea, Salix } \\
\text { salviifolia }\end{array}$ & $\begin{array}{l}\text { Alnus glutinosa, Salix } \\
\text { atrocinerea }\end{array}$ \\
\hline $\begin{array}{l}\text { Typical riparian } \\
\text { structure }\end{array}$ & $\begin{array}{l}\text { Trees, shrubs, ferns, } \\
\text { climbers, } \\
\text { graminoids, forbs }\end{array}$ & $\begin{array}{l}\text { Trees, shrubs, ferns, } \\
\text { climbers, } \\
\text { graminoids, forbs }\end{array}$ \\
\hline \multicolumn{3}{|l|}{$\begin{array}{l}\text { Environmental } \\
\text { features }\end{array}$} \\
\hline Annual rainfall (mm) & 730 & 760 \\
\hline $\begin{array}{l}\text { Average annual } \\
\text { temperature }\left({ }^{\circ} \mathrm{C}\right)\end{array}$ & 16.0 & 11.6 \\
\hline $\begin{array}{l}\text { Elevation range } \\
\quad \text { (masl) }\end{array}$ & $77-135$ & $20-80$ \\
\hline $\begin{array}{l}\text { Average drainage } \\
\text { basin area }\left(\mathrm{km}^{2}\right)\end{array}$ & $4.2-45$ & 84 \\
\hline Strahler order & $1-2$ & 1 \\
\hline Channel width (m) & $0.5-1.5$ & $0.5-1$ \\
\hline \multicolumn{3}{|l|}{ Local pressures } \\
\hline Margins & $\begin{array}{l}\text { Trampling, } \\
\text { prevention of } \\
\text { natural succession }\end{array}$ & $\begin{array}{l}\text { Grazing, trampling, } \\
\text { mowing }\end{array}$ \\
\hline Channel & Aggradation & Recalibration \\
\hline
\end{tabular}

and litter decomposability (Pérez-Harguindeguy et al., 2013). Dominant reproduction type (by seed or by vegetative sprouting) indicates the capacity of a plant species to resprout after destruction of most of its above-ground biomass and is thus an important attribute in terms of its persistence in ecosystems commonly subject to recurrent disturbances such as browsing or trampling by large herbivores (PérezHarguindeguy et al., 2013). We used the C-S-R (competitor, stress tolerant, and ruderal) ecological strategy classification of Grime (1977), which describes the species' strategy associated with resource availability and disturbance events. For example, C-strategists are expected to occur more frequently at later successional stages as disturbance frequency is assumed to be reduced (Wollny, Otte, \& Harvolk-Schöning, 2019).

We calculated the community-level weighted means (CWMs) of trait values as an index of functional composition, based on the list of species recorded (presence or absence) in the floristic inventories and on the species' functional traits. Then, we calculated functional dispersion (FDis) as a flexible index of functional diversity unaffected by species richness for French and Portuguese sites (Laliberté \& Legendre, 2010). FDis has been found to be a good indicator of habitat changes and disturbance in riparian ecosystems in comparison with other functional diversity indexes (Laliberté et al., 2010; Göthe, Timmermann, Januschke, \& Baattrup-Pedersen, 2016; Biswas, Mallik, Braithwaite \& Biswas, Mallik, Braithwaite, \& Biswas, 2019; Janssen, Piégay, Pont, \& Evette, 2019). Then, we compared community structure, functional composition (CWM), and functional diversity (FDis) at different stages of the PR process. Analyses were performed using the FD package in R (Laliberté, Legendre, \& Shipley, 2014). Comparisons among groups were performed by means of a nonparametric Kruskal-Wallis test (Sokal \& Rohlf, 1995).

\section{2 | Social perception: Semantic differential survey}

Perceptions of landscape aesthetics and of ecological quality were investigated by means of a semantic differential (SD) survey (Osgood, 1964), in which colour photographs were used as visual stimuli. Landscape perception studies have largely used oblique terrestrial photographs (e.g., Clay \& Daniel, 2000; Fyhri, Jacobsen, \& Tømmervik, 2009; Natori \& Chenoweth, 2008), as the representativity and reliability of this approach have been long established (Hull \& Stewart, 1992; Nassauer, 1983; Shafer \& Richards, 1974; Stamps, 1990; Stewart, Middleton, Downton, \& Ely, 1984). The SD approach is designed to measure the connotative meaning of objects, events, and concepts, based on the use of bipolar scales defined by Osgood (1964). Each bipolar scale consists of a pair of opposing concepts (or antonyms), which are usually adjectives, such as "ugly-beautiful" or "continuous-discontinuous." The present study employed such scales to determine a person's subjective perception of (or affective reaction to) the qualities of headwater river reaches. Qualities were then evaluated using a continuum of five scores linking the opposites in each scale, which respondents mark to show how they score the site under evaluation, according to the specific bipolar scale. A preliminary version of the survey form was developed using three sets of photographs (NR, ST, and LT) for both the Portuguese and the French study sites, each characterized by 23 bipolar scales. Visual stimuli used in the survey for both countries was a set of four photographs representative of each restoration stage condition (see the supporting information). Figure 2 presents illustrative examples of the photographs used in the survey for each country and stage of restoration.

After performing a first trial to ensure linguistic clarity and avoid redundancy, three bipolar scales were eliminated, leaving 20 scales grouped in the following four domains: "A-Scenic Quality," "B-Ecological Structure and Function," "C-Naturalness and Management," and "D-Functions and Services for Society" (Table 2; see also the Data S1 in supporting information). Furthermore, special care was taken in meeting the requirements and recommendations underpinning the SD approach (i.e., ensure the existence of sets of bipolar scales covering the whole domain, check for linguistic and 

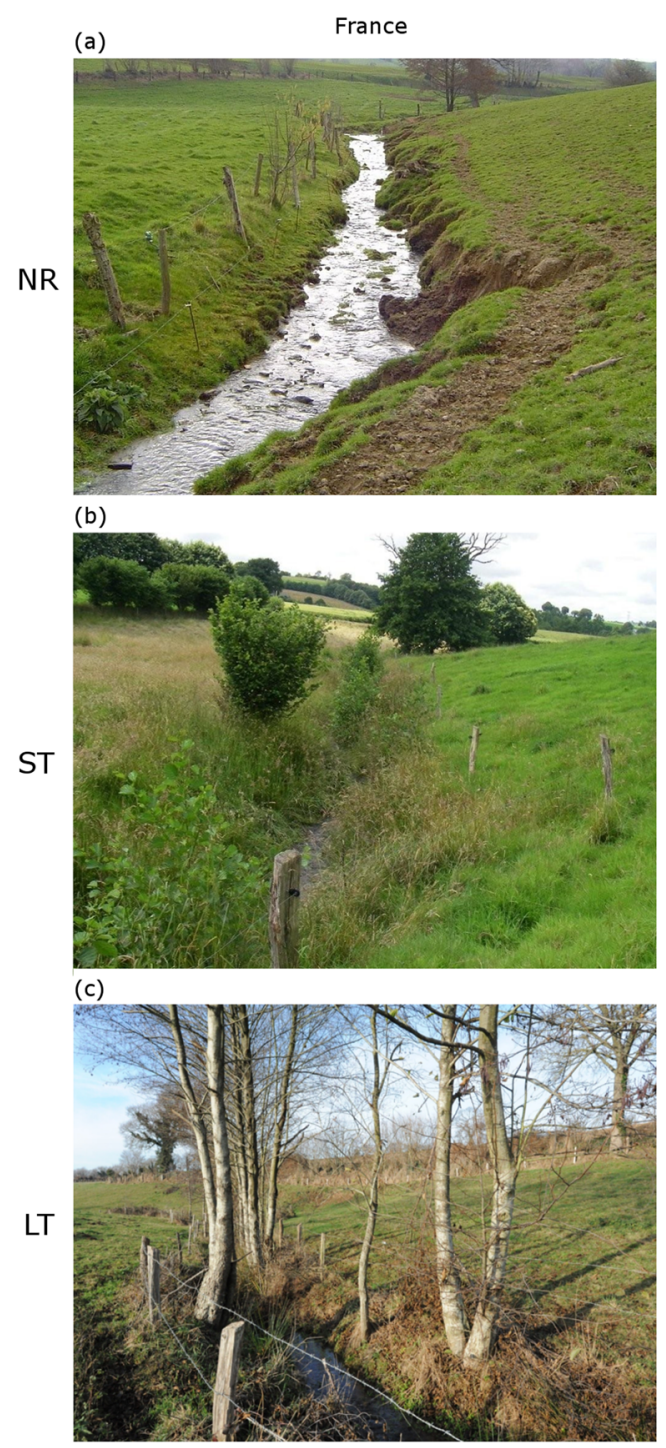

(d)

Portugal

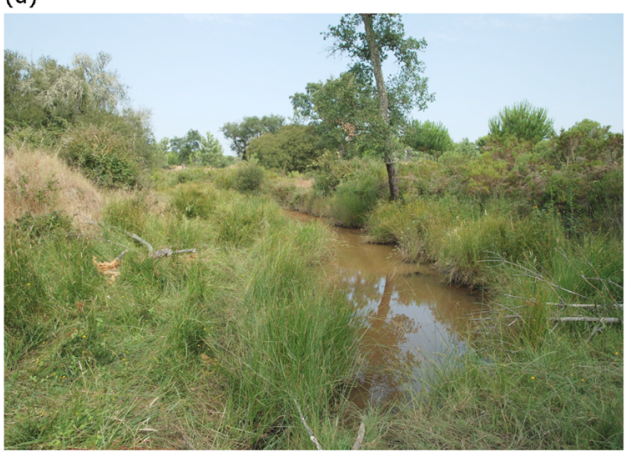

(e)

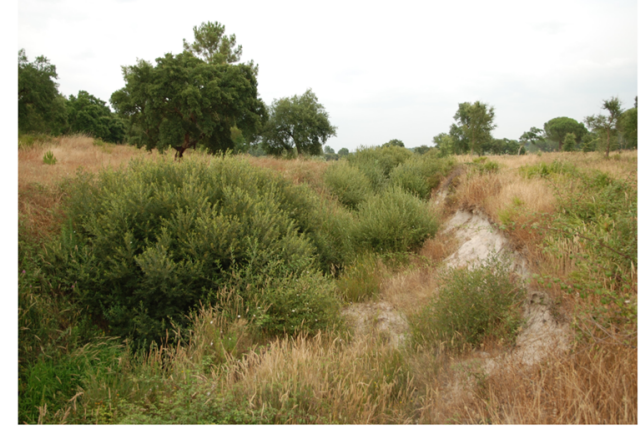

(f)

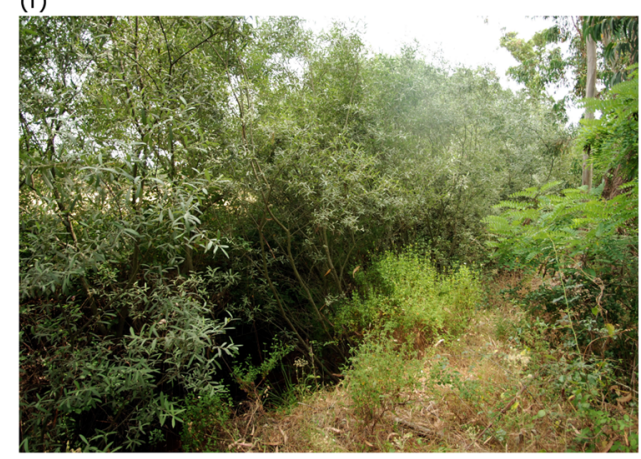

FIGURE 2 Sample of the photos used as visual stimuli for the French (a, nonrestored [NR]; b, short-term restored [ST]; and c, long-term restored [LT]) and the Portuguese sites (d, NR; e, ST; and f, LT) [Colour figure can be viewed at wileyonlinelibrary.com]

psychological bipolarity and linguistic clarity, maintain unidimensionality of the concept and distinctiveness of dimension(s), and avoid contextual contamination; Verhagen, Hooff, \& Meents, 2015).

A total of 86 stakeholders and students were surveyed; 23 were Portuguese stakeholders ( 7 landowners and 16 environmental managers), 10 were French stakeholders (all environmental managers), 26 were Portuguese landscape architecture students, and 27 were French geography students (Table 3 ). University students provide a convenient sampling pool due to their relatively uniform age structure. Several studies of scenic beauty show close agreement between the judgements of students and those of the general public (Le Lay et al., 2008). Respondents are assumed to be nonexperts because the students selected had not received specific training in the assessment of ecological condition of rivers prior to the survey. As one of the goals of the study is related to the effect of context and cultural background on perception, all respondents completed the full questionnaire (i.e., including both Portuguese and French photo sets). Out of the total number of respondents, $51 \%$ were male, and $49 \%$ were female, and the majority (86\%) were under 45 years old. Among the student respondents, eight individuals were of neither Portuguese nor French nationality, but all were European Union nationals. The reliability of the bipolar scales and the consistency of respondents were assessed using Cronbach's alpha, which took a satisfactory value of .79 (greater than the .70 threshold; see Desselle, 2005).

We performed a principal component analysis (PCA) on all the responses and used the scores of most relevant axis to test if there were any significant differences among following groups: geographical context of study areas (France vs. Portugal), stage in the restoration trajectory (NR, ST, and LT), social groups (students vs. landowners and managers), gender, age, education, and country of residence. We used $t$ tests for two group variables and ANOVA tests for three or more group variables. All statistical tests were performed using PAST software (Hammer, Harper, \& Ryan, 2001). 
TABLE 2 Bipolar scales used in the semantic differential survey, grouped by domain

\begin{tabular}{|c|c|}
\hline Domain & Bipolar scale \\
\hline A-Scenic Quality & $\begin{array}{l}\text { Unattractive-attractive } \\
\text { Repetitive-varied } \\
\text { Dirty-clean } \\
\text { Ugly-beautiful } \\
\text { Simple-complex }\end{array}$ \\
\hline $\begin{array}{l}\text { B-Ecological Structure and } \\
\text { Function }\end{array}$ & $\begin{array}{l}\text { Plant species poor-plant species rich } \\
\text { Discontinuous-continuous } \\
\text { Static-dynamic } \\
\text { Unstable-stable } \\
\text { Simplified-diversified }\end{array}$ \\
\hline $\begin{array}{l}\text { C-Naturalness and } \\
\text { Management }\end{array}$ & $\begin{array}{l}\text { Artificial-natural } \\
\text { Polluted-uncontaminated } \\
\text { Exotic invaders rich-exotic invaders poor } \\
\text { Neglected-cared for } \\
\text { High maintenance demanding-low } \\
\quad \text { maintenance demanding }\end{array}$ \\
\hline $\begin{array}{l}\text { D-Functions and Services } \\
\text { for Society }\end{array}$ & $\begin{array}{l}\text { Unattractive for fauna-attractive for fauna } \\
\text { Unproductive-productive } \\
\text { Erosion inducing-erosion hindering } \\
\text { Exposed-sheltering } \\
\text { Flood inducing-flood hindering }\end{array}$ \\
\hline
\end{tabular}

\section{3 | RESULTS}

\section{1 | Ecological condition}

The results of the ecological condition analysis (Figure 3) depict the changes experienced in riparian vegetation during the PR process. In both French and Portuguese study areas, there were significant increases in indicators of riparian formation structure and complexity, as illustrated by the significantly larger proportions of trees, shrubs, climbers, and ferns (Figure 3a) associated with longer times since restoration had started (French sites: $\mathrm{KW}-\mathrm{H}_{2,108}=45.16$, $p=.0000$; Portuguese sites $\left.\mathrm{KW}-\mathrm{H}_{2,10}=5.7273, p=.0057\right)$. The composition (CWM) of plant strategies (sensu Grime, 1977) illustrated the ecological changes occurring during ecological succession. Significantly higher CWM values for competitors (Figure 3c), characteristic of later successional stages, were found in long-term restoration in both the French $\left(\mathrm{KW}-\mathrm{HF}_{2,108}=32.2968, p=.0000\right)$ and Portuguese study areas $\left(\mathrm{KW}-\mathrm{H}_{2,10}=6.7455, p=.0343\right)$. The CWM values for ruderal species (Figure $3 \mathrm{~d}$ ), characteristic of disturbed or pioneer successional stages, showed an apparent but not significant decrease associated with long-term restoration in both Portuguese $\left(\mathrm{KW}-\mathrm{H}_{2,10}=1.6623, p=.4355\right)$ and French sites $\left(\mathrm{KW}-\mathrm{H}_{2,108}=\right.$ 1.3008, $p=.5218$ ). Absolute FDis values were higher in the Portuguese than in the French sites $\left(\mathrm{KW}-\mathrm{H}_{1,119}, p=.0001\right)$ and were significantly higher in the French study sites after long-term restoration $\left(\mathrm{KW}-\mathrm{H}_{2,10}=19.9986, p=.0000\right)$. Portuguese sites showed an apparent but not significant change increasing associated to shortterm restoration, which then decreased associated to long-term restoration $\left(\mathrm{KW}-\mathrm{H}_{2,10}=3.0727, p=0.2152\right)$. 

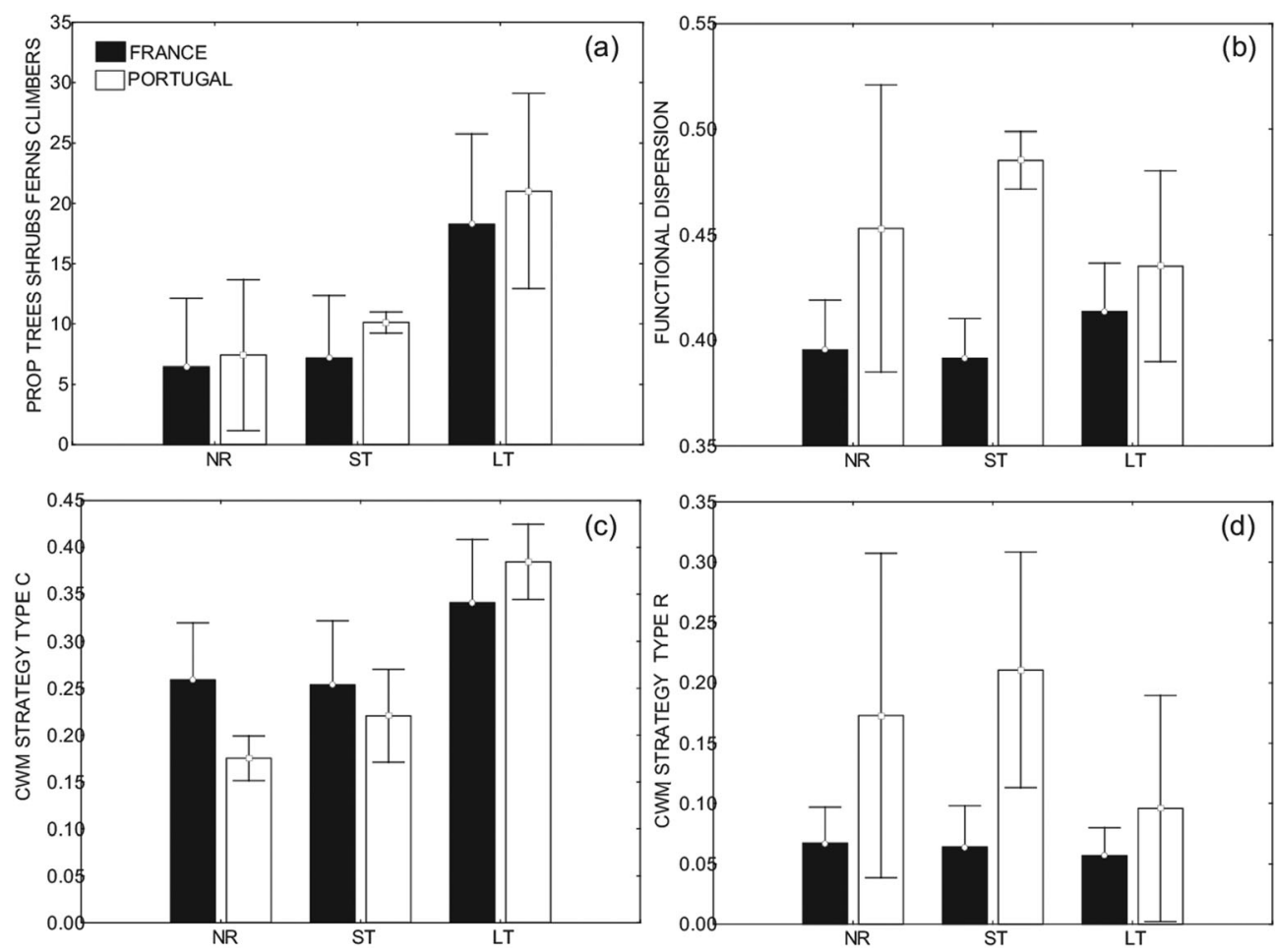

FIGURE 3 Changes in ecological condition, illustrated by the following riparian vegetation indicators (mean \pm standard deviation): (a) proportion of trees, shrubs, ferns, and climbers in the sampled plot; (b) functional dispersion; (c) community weighted means of C-competitor plant species (classified according to Grime, 1997) and (d) community weighted means of R-ruderal plant species (classified according to Grime, 1997) along the passive restoration process (NR, nonrestored; ST, short-term restored; LT, long-term restored) in both countries (full bars, France; open bars, Portugal). CWM, community-level weighted mean

\section{2 | SD analysis}

We did not observe significant differences in responses across gender, age, education, nationality, and country-of-residence groups. However, we did find significant differences between geographical contexts of the analysed photo sets, stage in the restoration trajectory, and level of experience of the respondents. Restored sites (ST and LT) and Portuguese sites had higher values along the first axis of the PCA (26\% of the variance) and lower values along the second axis of the PCA ( $13 \%$ of variance) than NR sites and French sites, respectively (Figure 4). This indicates that restored sites and Portuguese sites are perceived overall as more complex, plant-species rich, diverse, attractive for fauna, and erosion hindering $\left(R^{2}\right.$ values between the first axis and the variables were $.69, .74, .74, .71$, and.67, respectively), and less cared for $\left(R^{2}\right.$ values between the second axis and the variables is .77) than NR sites and French sites $(p<.005)$.

Despite these overall differences, a more detailed observation of the SD survey data reveals underlying complexity. This is apparent in Figure 5, where the positive side of the bipolar scale is on the right side of the graph and the negative side of the scale is on the left side of the graph, and the bipolar scales are grouped according to domain (A-Scenic Quality; B-Ecological Structure and Function; C-Naturalness and Management; and D-Functions and Services for Society) and ordered from top to bottom as presented in Table 2. In Figure 5, the mean value of bipolar scale scores attributed across the three stages of restoration (NR, ST, and LT) are displayed by domain, such that different social groups, respondent nationalities, and geographical contexts of the photo sets can be contrasted.

Regarding the ecological restoration process, we did not observe a regular pattern in perception of landscape changes along the three stages analysed in the restoration trajectory. The French restored sites received higher appreciation scores for 10 out of the 20 bipolar scales, especially for those in the "A-Scenic Quality" and "D-Functions and Services for Society" domains. Restored sites (especially LT sites) are perceived as more attractive, more complex, and more natural regardless of respondent social group or nationality. However, similar results in terms of positive appreciation associated with restoration were not obtained for the Portuguese sites. For example, contrary to the French restored sites, the Portuguese restored sites were not perceived as more diverse than the NR ones (domain "B-Ecological Structure and Function"). Conversely, the Portuguese restored sites are systematically considered less cared for (domain "C-Naturalness and Management").

Restoration was also perceived differently across respondent social group and nationality. For example, in the "D-Functions and Services for Society" domain, we observed different response patterns across different respondent experience levels for French sites and across different respondent nationalities for Portuguese sites. For French sites, stakeholders (both French and Portuguese) seem better 

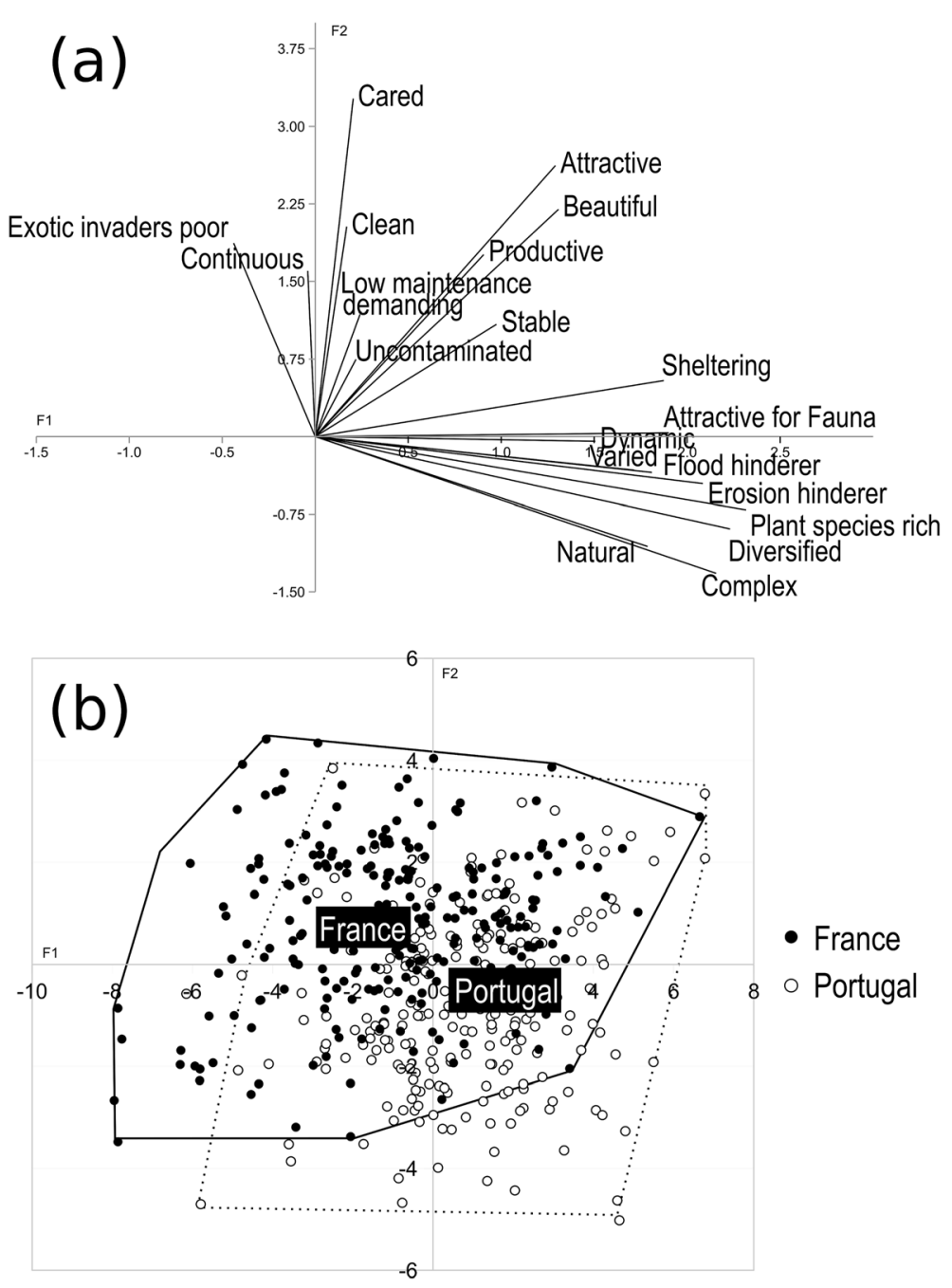

- France

FIGURE 4 Factorial maps of the principal component analysis performed on perception data from questionnaires, (a) bipolar scales, such that extreme of arrows point to the positive extreme score of bipolar scales; (b) and (c) show scatterplots of all bipolar scales scores labelled by the groups of variables that showed significant differences, that is, geographical contexts (b) and stage in the restoration trajectory (c). Convex hull volumes for groups of variables are displayed to facilitate visualization. Variances of Axes 1 and 2 are, respectively, $26 \%$ and $13 \%$. Differences between groups of other variables (age, gender, etc.) are not statistically significant. NR, nonrestored; ST, short-term restored; LT, long-term restored

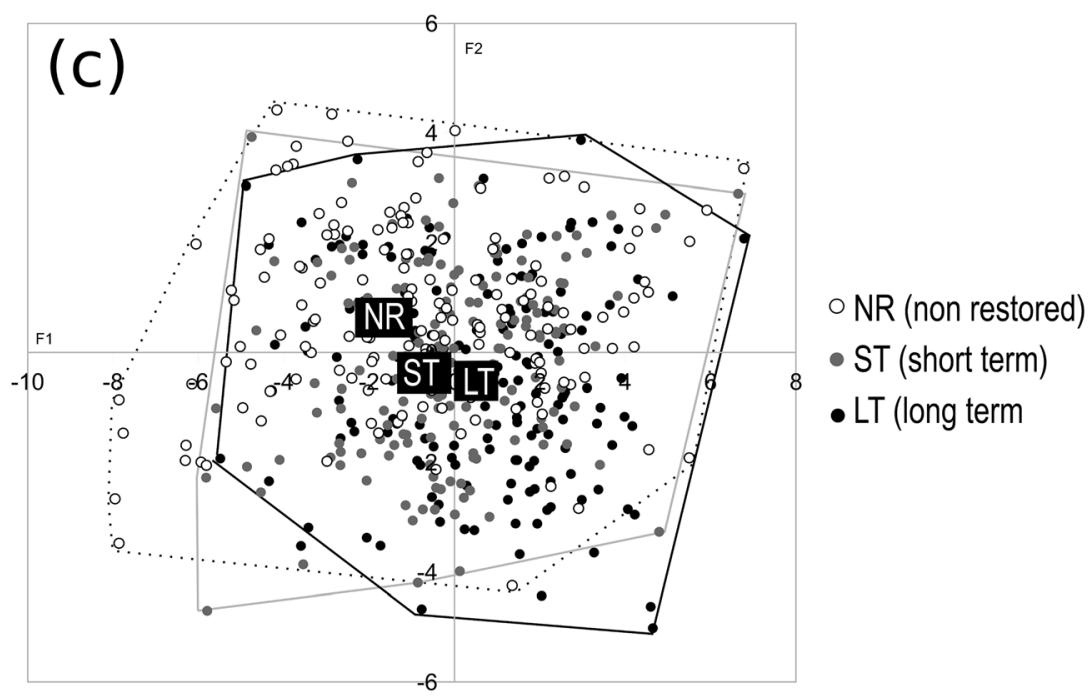

able to distinguish between the restoration stages, notably for the "attractive for fauna" and "productive" bipolar scales. Moreover, for Portuguese sites, the Portuguese respondents (students and stakeholders) seem to perceive differences less than the French respondents; this was the case for the "sheltering" and "flood hinderer" bipolar scales, for example.

\section{4 | DISCUSSION}

The analysis of ecological condition revealed that PR was generally associated with increases in ecological complexity and diversity in the assessed riparian communities in both geographical contexts, with poorly structured riparian communities being found in the NR sites 


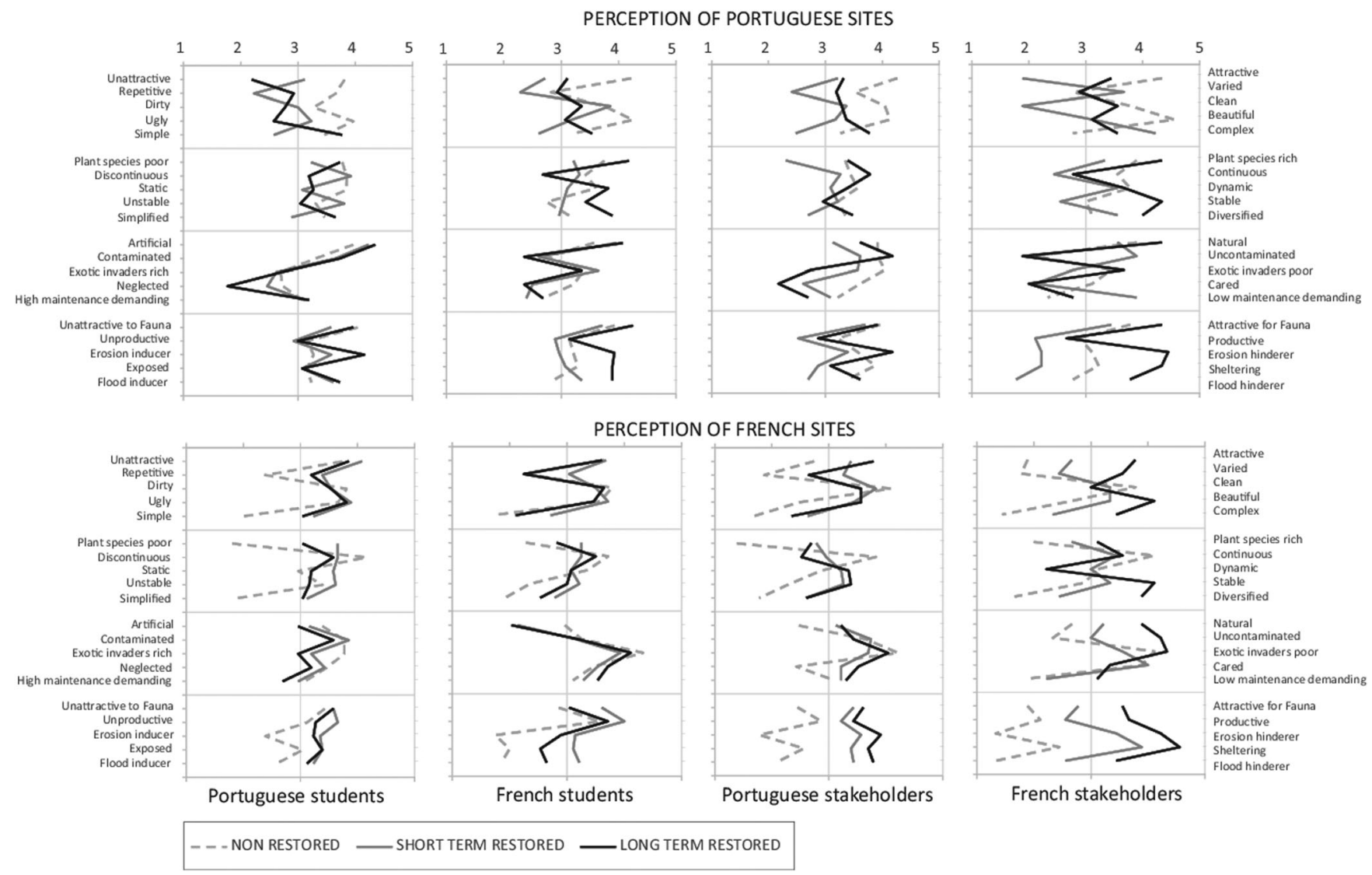

FIGURE 5 Representation of the mean evaluation scores of all sets of evaluated pictures (top, Portuguese sites; bottom, French sites) according to the 20 bipolar scales used in the survey, organized from top to bottom, grouped by domain (A, "Scenic Quality"; B,

"Ecological Structure and Function"; C, "Naturalness and Management"; D, "Functions and Services for Society") and displayed by stage in the restoration process (dashed line, nonrestored; grey line, short-term restored; black line, long-term restored); for each stage of the restoration process, the mean values of the bipolar scales within the same domain have been linked within the same line to facilitate the interpretation by domain

and relatively diverse and complex communities being found in the restored sites and especially in the $\mathrm{LT}$, as can be expected as a result of spontaneous vegetation succession (Prach et al., 2014). The absolute values of riparian FDis were different between the two geographical contexts, with the Portuguese sites having generally higher values of FDis than the French sites, whereas FDis in the French LT sites was significantly higher after long-term restoration compared with before restoration. This difference between geographical regions can be expected due to the different bioclimatic contexts and land uses. First, fluvial corridors in landscapes under Mediterranean climates typically support comparatively diverse riparian communities (Stella, Rodríguez-González, Dufour, \& Bendix, 2013). Portuguese riparian sites exhibit steep environmental gradients, from the upland Mediterranean cork-oak woodland to the riparian zone, enabling the coexistence of plants with contrasting ecological preferences and strategies (Araya et al., 2011) across relatively short distances. This is in contrast to the more humid landscape found in Normandy. Additionally, differences in functional diversity may reflect differences between the land-use matrices and degrees of land intensification of the extensive montado silvo- pastoral system in Portugal and the more intensively used landscape in Normandy (Laliberté et al., 2010).

The representation of the SD graphs enabled comparisons to be made between changes in ecological condition and people's perception of different restoration stages, both in Mediterranean (Portuguese) and in temperate (French) ecological contexts. Through this representation, it is possible to conclude that, in general, people perceive improvement in some ecological conditions or functions resulting from the restoration projects (such as species richness and protection against soil erosion), but that variation exists among different respondent social groups and nationalities, revealing a contextdependent pattern. In the case of the Portuguese sites (Figure 5), French respondents were particularly sensitive to the water condition (when presenting sediment in suspension, as seen in Figure $2 \mathrm{~d}$ ), which impacted the group's perception of the level of pollution in the water, thus lowering their aesthetic appreciation of the site. Furthermore, the large increase in the density of woody plants, which obstruct views of the water and hinder its flow across margins, may lower people's aesthetic appreciation of long-term restoration stages. This was quite evident in the case of the Portuguese student group and concurs with 
previously published results by Purcell et al. (2002) and subsequent comments by Kondolf and Yang (2008).

SD analysis showed that responses to the inquiry on aesthetic perceptions were significantly different among analysed groups and across the four perception domains. For certain domains, responses for some of the bipolar scales showed no differences among groups. For example, the responses in the "A-Scenic Quality" domain seemed to be linked to a more immediate aesthetic impression and less related to previous experience or educational background. This could be interpreted as an "initial affective reaction" in Ulrich's model of affective response to a natural scene (Ulrich, 1983). Experience and cultural background seemed to influence perception of changes in ecological condition across the restoration process in the remaining three domains ("B-Ecological Structure and Function," "C-Naturalness and Management," and "D-Functions and Services for Society"). In these domains, stakeholder groups attributed different scores, presumably due to their closeness to and experience in the ecological context. For example, French stakeholders clearly ranked the LT French photo sets as "stable," "diversified," "natural," "uncontaminated," and "sheltering" in contrast to French students (less experienced) and Portuguese respondents (more familiar with the Mediterranean context). Furthermore, stakeholders (both French and Portuguese) generally exhibited a more distinct attitude concerning the capacity of the riparian community to protect against bank erosion (a clear management issue), particularly when considering the long-term stages of recovery. According to Ulrich (1983), this could be interpreted as a response determined by a "post cognitive affective state," a less immediate stage in the perception process that is much more influenced by one's culture and experience (Figure 5). Ulrich's model is also in line with the findings of Zajonc (1980), according to which the occurrence of affective discriminations (like-dislike ratings) in the human mind happen "sooner than" and "independently of" the cognition processes supporting human judgments based on experience.

When analysing the changes in ecological condition and visual preference together along the restoration trajectory, we verify that the ecological changes implied by PR in the Portuguese photo sets tended to be negatively perceived from an aesthetical perspective and were scored more highly on the "neglected," "unproductive," and sometimes "polluted" bipolar scales. This contrasts with the result for the French photo sets and with the observations of Cottet et al. (2013) concerning aquatic wetlands. Although people's aesthetical preferences have provided good support for several river health indicators in other regions of the world, subtle cues of human modification were found to be associated with perceived higher environmental quality (McCormick et al., 2015). This is in line with our results, where visual "indicators of human intention to care" (Nassauer, 1995) were positively perceived. For example, the fact that the French long-term-restored photosets were better perceived may be related to the fact that they showed an apparently more managed vegetation cover with aligned trees and a low herbaceous layer, whereas the Portuguese LT site was characterized by a much denser and more shrubby vegetation. This is particularly relevant in a headwater context, where the geomorphological conditions of small rivers (Benda et al., 2005) might prevent attractive open views of the landscape, leading to lower appreciation by the public for reasons unrelated to the restoration process and due simply to intrinsic spatial features of headwaters.

Overall, our results confirm that aesthetical assessment is highly context dependent, and thus, the combination of ecological and social dimensions of restoration projects reveals the complexity of river restoration assessment. Moreover, recognizing ecological improvement is often dependent on technical experience; therefore, it can be perceived differently by different groups or by experts with different educational backgrounds. Misalignments between the recognition of improved ecological conditions and social acknowledgement of restoration interventions may lead to misunderstanding among managers, landowners, or other societal groups and may ultimately determine the success or failure of restoration (Jähnig et al., 2011). This highlights the need to monitor not only ecological improvement following river restoration but also to assess how restoration is perceived socially in order to promote effective engagement of stakeholders in the restoration process. Such assessment can be incorporated into the planning and design of the ecological restoration programme to better integrate positive social perception as an explicit key element of restoration.

\section{FUNDING INFORMATION}

The Portuguese Foundation for Science and Technology (FCT) supported P. M. R. G. and M. N. B. through FCT investigator programmes IF/00059/2015 and IF/01171/2014, respectively, the Forest Research Centre through projects UID/AGR/00239/2013 and PTDC/ASP-SIL/28593/2017 and LEAF through project UID/AGR/ 04129/2019. FCT and Campus France supported the SECODAM project (2015-2016) through the PROGRAMA PESSOA/Hubert Curien bilateral agreements. AESN, AFB/SNB (Ministère de l'Écologie), and ORE diaPFC supported research at INRA-Agrocampus Ouest. Support was provided by COST Action (CA16208) - CONVERGES: Knowledge Conversion for Enhancing Management of European Riparian Ecosystems and Services.

\section{ACKNOWLEDGEMENTS}

We acknowledge the students of landscape architecture (School of Agriculture, University of Lisbon, 2017-2018), students of geography (University of Rennes, 2017-2018), and stakeholders in Portugal who participated in the surveys (Portuguese Environment Agency [APA], Institute for Conservation of Nature and Forests [ICNF], EDIA, Municipality of Santarém, Municipality of Ponte de Lima, and ECOSALIX). Special thanks go to Conceição Silva from Coruche Forest Association (APFC) who facilitated access to the study areas and contacts with landowners in Portugal. We thank Jeffrey Anderson for the English review.

\section{CONFLICT OF INTEREST}

The authors declare that there is no conflict of interest that could be perceived as prejudicing the impartiality of the research reported. 


\section{ORCID}

Pedro Arsénio (D) https://orcid.org/0000-0003-3860-9789

Patricia María Rodríguez-González (D) https://orcid.org/0000-00018507-8429

\section{REFERENCES}

Agencia Estatal de Meteorologia \& Instituto de Meteorologia (2011). Iberian Climate Atlas. Agencia Estatal de Meteorología de España, Ministerio de Medio Ambiente y Medio Rural y Marino \& Instituto de Meteorologia de Portugal. Madrid/Lisboa.

Araya, Y. N., Silvertown, J., Gowing, D. J., McConway, K. J., Linder, H. P., \& Midgley, G. (2011). A fundamental, eco-hydrological basis for niche segregation in plant communities. New Phytologist, 189(1), 253-258. https://doi.org/10.1111/j.1469-8137.2010.03475.x

Benda, L., Hassan, M., Church, M., \& May, C. (2005). Geomorphology of steepland headwaters: The transition from hillslopes to channels. Journal of the American Water Resources Association, 41, 835-851. https:// doi.org/10.1111/j.1752-1688.2005.tb03773.x

Biswas, S. R., Mallik, A. U., Braithwaite, N. T., \& Biswas, P. L. (2019). Effects of disturbance type and microhabitat on species and functional diversity relationship in stream-bank plant communities. Forest Ecology and Management, 432, 812-822. https://doi.org/10.1016/j.foreco. 2018.10.021

Brooks, R., \& Colburn, E. (2011). Extent and channel morphology of unmapped headwater stream segments of the Quabbin Watershed, Massachusetts. Journal of the American Water Resources Association, 47(1), 158-168. https://doi.org/10.1111/j.1752-1688.2010.00499.x

Castroviejo, S., Laínz, M., López González, G., Montserrat, P., Paiva, J., \& Villar, L. (Eds.) (1986-2015). Flora iberica. Plantas vasculares de la Península Ibérica e Islas Baleares (Vols. 1-8, 10-15, 17-18, 20-21). Madrid: Real Jardín Botánico - Consejo Superior de Investigaciones Científicas.

Chandesris, A., Wasson, J.G., Pella, H., Sauquet, E., Mengin, N. (2006). Appui scientifique à la mise en oeuvre de la Directive cadre européenne sur l'eau. Typologie des cours d'eau de France métropolitaine. 63 p. [available at http://cemadoc.cemagref.fr/cemoa/ PUB00021163]

Chin, A., Laurencio, L. R., Daniels, M. D., Wohl, E., Urban, M. A., Boyer, K. L., ... Gregory, K. J. (2014). The significance of perceptions and feedbacks for effectively managing wood in rivers. River Research and Applications, 30(1), 98-111. https://doi.org/10.1002/rra.2617

Clay, G. R., \& Daniel, T. C. (2000). Scenic landscape assessment: The effects of land management jurisdiction on public perception of scenic beauty. Landscape and Urban Planning, 49(1-2), 1-13. https://doi.org/ 10.1016/S0169-2046(00)00055-4

Cottet, M., Piégay, H., \& Bornette, G. (2013). Does human perception of wetland aesthetics and healthiness relate to ecological functioning? Journal of Environmental Management, 128, 1012-1022. https://doi. org/10.1016/j.jenvman.2013.06.056

Cottet, M., Piola, F., Le Lay, Y.-F., Rouifed, S., \& Rivière-Honegger, A. (2015). How environmental managers perceive and approach the issue of invasive species: The case of Japanese knotweed s.l. (Rhône River, France). Biological Invasions, 17(12), 3433-3453. https://doi.org/ 10.1007/s10530-015-0969-1

Desselle, S. P. (2005). Construction, implementation, and analysis of summated rating attitude scales. American Journal of Pharmaceutical Education, 69(5), 97. https://doi.org/10.5688/aj690597

Dias, F. S., Bugalho, M. N., Rodríguez-González, P. M., Albuquerque, A., \& Cerdeira, J. O. (2015). Effects of forest certification on the ecological condition of Mediterranean streams. Journal of Applied Ecology, 52(1), 190-198. https://doi.org/10.1111/1365-2664.12358
Dufour, S., \& Piégay, H. (2009). From the myth of a lost paradise to targeted river restoration: forget natural references and focus on human benefits. River Research and Applications, 25(5), 568-581. https://doi.org/10.1002/rra.1239

Dufour, S., Rodríguez-González, P. M., \& Laslier, M. (2019). Tracing the scientific trajectory of riparian vegetation studies: Main topics, approaches and needs in a globally changing world. Science of the Total Environment, 653, 1168-1185. https://doi.org/10.1016/j.scitotenv. 2018.10.383

Forget, G., Carreau, C., Coeur, D. L., \& Bernez, I. (2013). Ecological restoration of headwaters in a rural landscape (Normandy, France): A passive approach taking hedge networks into account for riparian tree recruitment. Restoration Ecology, 21(1), 96-104. https://doi.org/10.1111/ j.1526-100X.2012.00868.x

Fyhri, A., Jacobsen, J. K. S., \& Tømmervik, H. (2009). Tourists' landscape perceptions and preferences in a Scandinavian coastal region. Landscape and Urban Planning, 91(4), 202-211. https://doi.org/10.1016/j. landurbplan.2009.01.002

Gobster, P., Nassauer, J., Daniel, T., \& Fry, G. (2007). The shared landscape: What does aesthetics have to do with ecology? Landscape Ecology, 22(7), 959-972. https://doi.org/10.1007/s10980-007-9110-x

Gobster, P. H., \& Hull, R. B. (2000). Restoring nature: Perspectives from the social sciences and humanities. Washington, D.C: Island Press.

Göthe, E., Timmermann, A., Januschke, K., \& Baattrup-Pedersen, A. (2016). Structural and functional responses of floodplain vegetation to stream ecosystem restoration. Hydrobiologia, 769(1), 79-92. https://doi.org/ 10.1007/s10750-015-2401-3

Grime, J. P. (1977). Evidence for the existence of three primary strategies in plants and its relevance to ecological and evolutionary theory. The American Naturalist, 111(982), 1169-1194. https://doi.org/10.1086/ 283244

Hammer, Ø., Harper, D. A., \& Ryan, P. D. (2001). PAST: paleontological statistics software package for education and data analysis. Palaeontologia Electronica, 4(1), 9.

Hands, D. E., \& Brown, R. D. (2002). Enhancing visual preference of ecological rehabilitation sites. Landscape and Urban Planning, 58(1), 57-70. https://doi.org/10.1016/S0169-2046(01)00240-7

Holl, K. D., \& Aide, T. M. (2011). When and where to actively restore ecosystems? Forest Ecology and Management, 261(10), 1558-1563. https://doi.org/10.1016/j.foreco.2010.07.004

Hong, C.-Y., Chang, H., \& Chung, E.-S. (2018). Resident perceptions of urban stream restoration and water quality in South Korea. River Research and Applications, 34(5), 481-492. https://doi.org/10.1002/ rra.3265

Hughes, F. M. R., Colston, A., \& Mountford, J. O. (2005). Restoring riparian ecosystems: The challenge of accommodating variability and designing restoration trajectories. Ecology and Society, 10(1), 12. Retrieved from. http://www.ecologyandsociety.org/vol10/iss1/art12/

Hull, R. B. IV, \& Stewart, W. P. (1992). Validity of photo-based scenic beauty judgments. Journal of Environmental Psychology, 12(2), 101-114. https://doi.org/10.1016/S0272-4944(05)80063-5

Instituto Nacional da Água. (2008). Tipologia de Rios Em Portugal Continental No âmbito da Implementação da Diretiva Quadro da água ICaracterização Abiótica. Ministério do Ambiente, do Ordenamento do Território e do Desenvolvimento Regional, Instituto Nacional da Agua, I.P., Lisboa, Portugal.

Jähnig, S. C., Lorenz, A. W., Hering, D., Antons, C., Sundermann, A., Jedicke, E., \& Haase, P. (2011). River restoration success: A question of perception. Ecological Applications, 21(6), 2007-2015. https://doi.org/ 10.1890/10-0618.1 
Janssen, P., Piégay, H., Pont, B., \& Evette, A. (2019). How maintenance and restoration measures mediate the response of riparian plant functional composition to environmental gradients on channel margins: Insights from a highly degraded large river. Science of the Total Environment, 656, 1312-1325. https://doi.org/10.1016/j.scitotenv.2018.11.434

Junker, B., \& Buchecker, M. (2008). Aesthetic preferences versus ecological objectives in river restorations. Landscape and Urban Planning, 85(3), 141-154. https://doi.org/10.1016/j.landurbplan.2007.11.002

Klotz, S., Kühn, I., \& Durka, W. (2002). Biolflor: Eine Datenbank zu biologisch-ökologischen Merkmalen der Gefäßpflanzen in Deutschland-Schriftenreihe für Vegetationskunde 38 (Version Version 1.1 (Web-Service)). Bonn: Bundesamt für Naturschutz: Dept. Community Ecology, UFZ - Centre for Environmental Research. Retrieved from https://www.ufz.de/biolflor/index.jsp

Kondolf, G. M., \& Yang, C.-N. (2008). Planning river restoration projects: Social and cultural dimensions. In S. Darby, \& D. Sear (Eds.), River Restoration (pp. 41-60). Chichester, West Sussex PO19 8SQ, England: John Wiley \& Sons, Ltd. https://doi.org/10.1002/9780470867082.ch4

Laliberté, E., \& Legendre, P. (2010). A distance-based framework for measuring functional diversity from multiple traits. Ecology, 91(1), 299-305. https://doi.org/10.1890/08-2244.1

Laliberté, E., Legendre, P., \& Shipley, B. (2014). FD: Measuring functional diversity from multiple traits, and other tools for functional ecology (Version R package version 1.0-12). Retrieved from https://cran.r-project.org/web/packages/FD/index.html

Laliberté, E., Wells, J. A., DeClerck, F., Metcalfe, D. J., Catterall, C. P., Queiroz, C., ... Mayfield, M. M. (2010). Land-use intensification reduces functional redundancy and response diversity in plant communities. Ecology Letters, 13(1), 76-86. https://doi.org/10.1111/j.14610248.2009.01403.x

Le Lay, Y., Piégay, H., Gregory, K., Chin, A., Dolédec, S., Elosegi, A., ... Zawiejska, J. (2008). Variations in cross-cultural perception of riverscapes in relation to in-channel wood. Transactions of the Institute of British Geographers, 33(2), 268-287. https://doi.org/10.1111/ j.1475-5661.2008.00297.x

Mallik, A. U., Newaz, S., Mackereth, R. W., \& Shahi, C. (2011). Geomorphic changes of headwater systems 3-23 years after forest harvesting by clearcutting. Ecosphere, 2(4), art43. https://doi.org/10.1890/es1000144.1

McCormick, A., Fisher, K., \& Brierley, G. (2015). Quantitative assessment of the relationships among ecological, morphological and aesthetic values in a river rehabilitation initiative. Journal of Environmental Management, 153, 60-67. https://doi.org/10.1016/j.jenvman.2014. 11.025

McGill, B. J., Enquist, B. J., Weiher, E., \& Westoby, M. (2006). Rebuilding community ecology form functional traits. Trends in Ecology \& Evolution, 21(4), 178-185. https://doi.org/10.1016/j.tree.2006.02.002

Naiman, R. J., Décamps, H., \& McClain, M. E. (2005). Riparia: ecology, conservation, and management of streamside communities. Amsterdam: Elsevier, Academic Press.

Nassauer, J. I. (1983). Framing the landscape in photographic simulation. Journal of Environmental Management, 17(1), 1-16.

Nassauer, J. I. (1995). Messy ecosystems, orderly frames. Landscape Journal, 14(2), 161-170. https://doi.org/10.3368/lj.14.2.161

Natori, Y., \& Chenoweth, R. (2008). Differences in rural landscape perceptions and preferences between farmers and naturalists. Journal of Environmental Psychology, 28(3), 250-267. https://doi.org/10.1016/j. jenvp.2008.02.002

Nomiya, H., Suzuki, W., Kanazashi, T., Shibata, M., Tanaka, H., \& Nakashizuka, T. (2003). The response of forest floor vegetation and tree regeneration to deer exclusion and disturbance in a riparian deciduous forest, central Japan. Plant Ecology, 164(2), 263-276. https://doi.org/10.1023/a:1021294021438

Osgood, C. E. (1964). Semantic differential technique in the comparative study of cultures ${ }^{1}$. American Anthropologist, 66(3), 171-200. https:// doi.org/10.1525/aa.1964.66.3.02a00880

Painter, L. E., Beschta, R. L., Larsen, E. J., \& Ripple, W. J. (2018). Aspen recruitment in the Yellowstone region linked to reduced herbivory after large carnivore restoration. Ecosphere, 9(8), e02376. https://doi.org/ $10.1002 /$ ecs 2.2376

Pérez-Harguindeguy, N., Díaz, S., Garnier, E., Lavorel, S., Poorter, H., Jaureguiberry, P., ... Cornelissen, J. H. C. (2013). New handbook for standardised measurement of plant functional traits worldwide. Australian Journal of Botany, 61(3), 167-234. https://doi.org/10.1071/ BT12225

Pickett, S. T. A. (1989). Space-for-time substitution as an alternative to long-term studies. In G. E. Likens (Ed.), Long-term studies in ecology: Approaches and alternatives (pp. 110-135). New York: Springer.

Piégay, H., Gregory, K. J., Bondarev, V., Chin, A., Dahlstrom, N., Elosegi, A., ... Zawiejska, J. (2005). Public perception as a barrier to introducing wood in rivers for restoration purposes. Environmental Management, 36(5), 665-674. https://doi.org/10.1007/s00267-004-0092-z

Prach, K., Řehounková, K., Lencová, K., Jírová, A., Konvalinková, P., Mudrák, O., ... Pyšek, P. (2014). Vegetation succession in restoration of disturbed sites in Central Europe: The direction of succession and species richness across 19 seres. Applied Vegetation Science, 17(2), 193-200. https://doi.org/10.1111/avsc.12064

Purcell, A. H., Friedrich, C., \& Resh, V. H. (2002). An assessment of a small urban stream restoration project in Northern California. Restoration Ecology, 10(4), 685-694. https://doi.org/10.1046/j.1526-100X.2002. 01049.x

Raunkiaer, C. (1934). The life forms of plants and statistical plant geography; being the collected papers of $\mathrm{C}$. Raunkiaer. Oxford: Clarendon Press.

Sawtschuk, J., Delisle, M., Mesmin, X., \& Bernez, I. (2014). How past riparian management practices can affect composition and structure of vegetation for headwater ecological restoration projects. Acta Botanica Gallica, 161(3), 309-320. https://doi.org/10.1080/12538078.2014. 933362

Shafer, E. \& Richards, T. A. (1974). A comparison of viewer reactions to outdoor scenes and photographs of those scenes (No. USDA Forest Service Research Paper NE-302; p. 26). http://www.fs.fed.us/ne/newtown_square/publications/research_papers/pdfs/scanned/OCR/ne_ rp302.pdf

Sokal, R. R., \& Rohlf, F. J. (1995). Biometry: The principles and practice of statistics in biological research (3rd ed.). New York: W.H. Freeman.

Stace, C. (2010). New flora of the British Isles. Cambridge: Cambridge University Press.

Stamps, A. E. (1990). Use of Photographs to Simulate Environments: A Meta-Analysis. Perceptual and Motor Skills, 71(3), 907-913. https:// doi.org/10.2466/pms.1990.71.3.907

Stella, J. C., Rodríguez-González, P. M., Dufour, S., \& Bendix, J. (2013). Riparian vegetation research in Mediterranean-climate regions: Common patterns, ecological processes, and considerations for management. Hydrobiologia, 719(1), 291-315. https://doi.org/ 10.1007/s10750-012-1304-9

Stewart, T. R., Middleton, P., Downton, M., \& Ely, D. (1984). Judgments of photographs vs. field observations in studies of perception and judgment of the visual environment. Journal of Environmental Psychology, 4(4), 283-302. https://doi.org/10.1016/S0272-4944(84) 80001-8 
Swart, J. A., Zevenberg, J., Ho, P., Cortina, J., Reed, M., Derak, M., ... Van der Windt, H. J. (2018). Involving society in restoration and conservation. Restoration Ecology, 26(S1), S3-S6. https://doi.org/10.1111/ rec.12709

Ulrich, R. S. (1983). Aesthetic and affective response to natural environment. In I. Altman, \& J. F. Wohlwill (Eds.), Behaviour and the natural environment (pp. 85-125). Boston, MA: Springer US. https://doi.org/ 10.1007/978-1-4613-3539-9_4

Van den Berg, A. E., \& Koole, S. L. (2006). New wilderness in the Netherlands: An investigation of visual preferences for nature development landscapes. Landscape and Urban Planning, 78(4), 362-372. https:// doi.org/10.1016/j.landurbplan.2005.11.006

Van Looy, K., Tonkin, J. D., Floury, M., Leigh, C., Soininen, J., Larsen, S., ... Datry, T. (2019). The three Rs of river ecosystem resilience: Resources, recruitment, and refugia. River Research and Applications, 35(2), 107-120. https://doi.org/10.1002/rra.3396

Verhagen, T., Hooff, B., \& Meents, S. (2015). Toward a better use of the semantic differential in IS research: An integrative framework of suggested action. Journal of the Association for Information Systems, 16(2), Article 1), 108-143. Retrieved from. http://aisel.aisnet.org/jais/vol16/ iss2/1, https://doi.org/10.17705/1jais.00388

Whittaker, R. H. (1975). Communities and ecosystems (2d ed.). New York: Macmillan.

Wollny, J. T., Otte, A., \& Harvolk-Schöning, S. (2019). Dominance of competitors in riparian plant species composition along constructed banks of the German rivers Main and Danube. Ecological Engineering, 127, 324-337. https://doi.org/10.1016/j.ecoleng.2018.11.013

Zahawi, R. A., Reid, J. L., \& Holl, K. D. (2014). Hidden costs of passive restoration. Restoration Ecology, 22(3), 284-287. https://doi.org/10.1111/ rec.12098

Zajonc, R. B. (1980). Feeling and thinking: Preferences need no inferences. American Psychologist, 35(2), 151-175. https://doi.org/10.1037/0003066X.35.2.151

Zhao, J., Wang, R., Luo, P., Xing, L., \& Sun, T. (2017). Visual ecology: Exploring the relationships between ecological quality and aesthetic preference. Landscape and Ecological Engineering, 13(1), 107-118. https://doi.org/10.1007/s11355-016-0306-6

\section{SUPPORTING INFORMATION}

Additional supporting information may be found online in the Supporting Information section at the end of the article.

How to cite this article: Arsénio P, Rodríguez-González PM, Bernez I, S. Dias F, Bugalho MN, Dufour S. Riparian vegetation restoration: Does social perception reflect ecological value? River Res Applic. 2019;1-14. https://doi.org/10.1002/rra.3514 